\title{
The Floral Morphology of the Genus Sebaea.
}

\author{
BY
}

\author{
ARTHUR W. HILL, M.A., F.L.S. \\ Assistant Director, Royal Botanic Gardens, Kew.
}

With Plate XXXV and two Figures in the Text.

OWARDS the close of the year 1907, when commencing work on the
South African species of the genus Sebaea (Gentianaceae) for the 'Flora Capensis', my attention was very soon drawn to the curious pair of swellings or glands which were usually to be seen on the style, below the level of the anthers. After microscopic examination of herbarium material of a number of flowers of different species, it seemed fairly certain that these two glandular bodies must be stigmatic in character. Pollen-grains were observed closely attached to their surface, and in the case of S. imbricata were seen to have germinated, but the material was for the most part too much withered and dried to allow of proper investigation. In order to verify the supposition that Sebaea possessed auxiliary stigmatic surfaces, fresh material was essential. Owing to the kindness of Professor H. H.W. Pearson, the late Dr. H. Bolus, Mr. J. Burtt Davy, Dr. R. Marloth, and Mr. W. C. Worsdell, seeds of several species of Sebaea were sent to Kew in the spring of 1908 and onwards, from which a good supply of plants was raised for experimental purposes.

After the first batch of plants had been raised and several experiments on the secondary stigma had been made, ${ }^{1}$ an abstract of a paper was

1 The possible stigmatic character of the swellings was first raised in a letter from Kew to Mr. Pole Evans, Mycologist to the Transvaal Department of Agriculture, on December 23, 1907. On February 7, 1908, letters were written to Professor Pearson and to Dr. Bolus at the Cape, drawing their attention to these swellings and asking them both to make observations and also to send seeds in order that experiments could be undertaken at Kew. Dr. Bolus very kindly sent seeds of Sebaea aurea on March 6, 1908. He wrote: 'Your note of Feb. 7 asking for seeds of Sebaea came by last mail. We lost no time in searching, and were fortunate in getting seed of Sebaea aurea, R.Br., our commonest species, although it is very late for it'; and on August 26 he wrote again in answer to a further letter written August I, asking him to carry out experiments in S. Africa with reference to the secondary stigma: "We shall do what we can in regard to observations on the living plants, as to the parasitism and as to the supposed fertilization by means of a secondary stigma below the apex of the style. But you must not expect much. My walking days are over and I can seldom get so far as where our best plants grow.'

Seeds of other species of Sebaea were sown in May, I908, some of which were received direct

[Annals of Botany, Vol. XXVII. No. CVII. July, 1913.] 
received from Dr. Marloth, which he had read at a meeting of the Royal Society of South Africa on September I6, I908. In this paper he described the secondary stigma in Sebaea exacoides.

On receiving Dr. Marloth's full paper, ${ }^{1}$ published in July, I909, I found that he had reached the same conclusion, with regard to the stigmas of Sebaea exacoides, to which I had been led from an examination of the whole genus and by the series of experiments shortly to be described.

Although the results of this work have to some extent been forestalled by the publication of Dr. Marloth's interesting observations made in South Africa, they seem worthy of being placed on record as an independent account of the peculiar floral structure which obtains in the genus. As a further extenuating circumstance, it may be pointed out that the investigation has been carried out on lines different from those followed by Dr. Marloth.

The Natural Order Gentianaceae shows several peculiarities of stigmatic arrangement in the different genera, which appear to be correlated with the structure of the corolla. Examples of dimorphic heterostylism are found in the genera Exochaenium, ${ }^{2}$ Hockinia, and to a slight extent in Lisianthus, all genera in which there is a well-marked corolla tube, and it seems possible that this condition may also occur in the genus Sebaea itself. Then in Pleurogyne, ${ }^{3}$ with its widely open and almost polypetalous flowers, the stigmatic surfaces form two bands down the sides of the ovary and the normal apical stigma appears to be more or less functionless (see Figs. I and 2, Pl. XXXV).

In Sebaea, where there is a distinct and more or less cylindrical corolla tube, the style is usually elongated. The stigma at its apex may be clavate, capitate, or in many cases shortly bilabiate. Except in the two species included in the sub-group Brevistylae, ${ }^{4}$ S. spathulata (P1. XXXV,

from Mr. Burtt Davy, and some collected from the dried material sent over from the Transvaal Herbarium for identification. From the seeds so obtained numerous plants were raised and afforded ample material for experiment.

On October 7 of the same year Dr. Marloth kindly sent seeds of Sebaea (Belmontia) cordata, and wrote as follows: "The box also contains some seeds of Belmontia cordata, as I heard from Dr. Bolus that in connexion with the Part on Gentianaceae for the "Flora Capensis" you wished to raise some plants from seed. I take the liberty of enclosing an abstract of a paper on some biological features of Belmontia.'

To complete the record of the seeds sown at Kew a packet of seed of Sebaea ambigua was received from $\mathrm{Mr}$. Worsdell, from the Cape, in April, I9I0, which also yielded some interesting seedlings, and I desire here to acknowledge my indebtedness to all who have kindly assisted me by sending seeds from South Africa.

1 Marloth, R. : 'A Diplostigmatic Plant,'Sebaea exacoides, (L.) Schinz, in Trans. Roy. Soc. of S. Africa, vol. i, pt. I.

2 See A. W. Hill in Kew Bull., I908, pp. 336-40 with Plate.

3 See Engler und Prantl, iv. 2, p. 87, Figs. D, E, esp. P. carinthiaca. Huxley, in his paper on the Gentians in Journ. Linn. Soc., xxiv, pp. I03, \&c., refers to the types of corolla, but does not describe the stigmatic arrangements in any of the genera.

4 A. W. Hill in Kew Bull., I908, p. 320 ; F1. Cap. iv. I, pp. I062, I092. See also p. 487. 
Figs. 24, 25) and S. Thomasii, and in the Indian species S. Khasiana, Clarke (P1. XXXV, Figs. 9-II), the base of the stigma proper is well above the level of the tops of the anthers. In the latter species, however, the stigma and anthers are at the same level, so that self-pollination can easily be effected, and in the Brevistylae the short stigma scarcely reaches to the level of the base of the anthers.

Another point which should be noticed in considering the floral morphology of the genus is that almost all the species appear to be markedly protandrous, the anthers opening when the flowers are still in bud. $S$. ambigua, as grown from seed at Kew, appears, however, to be an exception, as the anthers, though mature before the stigma, did not open until the flowers had expanded (Pl. XXXV, Fig. I4).

The flowers throughout the genus are orange-yellow, or white in exceptional cases. The corolla lobes are usually about equal in length to the tube, ${ }^{1}$ and they are spread out flat during a bright day. The corolla tube is usually thin-walled and elastic, and is often slightly constricted at the throat. When the ovary begins to swell it is usually closely embraced by the corolla tube.

The anthers are capped in nearly all the species by a small yellow gland, and in some species there are two glands at their base in addition.

In a few species the apical gland is large and nearly black (S. Thodeana, \&c.).

The anthers, when the flower is open, are conspicuous, and in many species stand clear of the outspread lobes with the style capped by the stigma rising above them. But where the anther filaments are inserted at some distance below the sinuses, or where the corolla lobes do not open so widely, the stamens are more or less included in the corolla tube, and in such a species as $S$. Thodeana (Pl. XXXV, Fig. 25) only the large apical glands of the anther are visible, while in $S$. Thomasii they are included in the tube after the manner of Exochaenium. The individual flowers last for two or three days, but they close regularly at dusk, and also when the sky is overcast. With the final withering of the flower there is considerable torsion of the corolla, which may have an important function in self-pollination, as will presently appear.

The peculiar organ or organs of the flowers of Sebaea may now be described. It has already been mentioned that, with certain exceptions, the stigma stands well above the tops of the anthers, so that self-pollination is impossible. There are, however, the two swellings on the style below the level of the base of the anthers, and therefore within the corolla tube, which have been found to occur in the large majority of the species of Sebaea. Though these swellings have been mentioned by others, their

${ }^{1}$ Huxley (Journ. Linn. Soc., xxiv, p. 109) places the genus in his group Lissanthe and the corolla is described as infundibulate. 
stigmatic nature does not appear to have been suspected, and it was not until living plants could be examined that these bodies were definitely proved to be efficient stigmas.

In some species the secondary stigmas are much more in evidence than in others, and as a rule they are not well defined in the newly-opened flower. While the flower remains open, however, they become more prominent, and in withered flowers they are often seen to be much enlarged and covered with pollen, which seems to have been brought into contact with the stigmatic surfaces largely by the constriction of the throat of the corolla tube due to torsion. Some pollen, no doubt, is shed on the secondary stigmas when the anthers open in the bud, and may eventually germinate; but it seems probable that the somewhat late development of the lower stigmas may be related to the time of ripening of the terminal stigma, and be so arranged that self-fertilization by way of the lower stigmas shall not take place until the pollination of the terminal stigma has become impossible.

The arrangement of three stigmatic surfaces disposed in this way on the same style is, I believe, unique in the Vegetable Kingdom, and in order to understand their relationship to each other and to the stigmatic arrangements typical of the Gentians, it is necessary in the first place to give a short account of the typical terminal stigma and its modifications. In the simplest cases the terminal stigma would appear to be a bilabiate structure, corresponding to the two carpels, with the stigmatic papillae borne only on the inner surfaces of the lobes. Stigmas of this type are well shown by $S$. ambigua (Pl. XXXV, Fig. I 8 ) and in most specimens of $S$. aurea (Fig. 5). Many species are very variable, and though the bilabiate character is apparent the lips do not as a rule open widely, but are pressed closely together, leaving only a small cleft at the apex. The edges of the stigmatic lobes, however, are often somewhat rolled over, so that there is a fairly large surface exposed over the top of the stigma and down its sides as far as the base of the cleft or primitive lobes.

A further stage is represented by those species in which the stigma is truly clavate and all trace of the bilabiate structure is obliterated, the stigmatic area being more or less disposed in a band passing over the top of the stigma and continued for a certain distance on either side (Pl. XXXV, Figs. I 3, 20).

The relation of the primary terminal stigma to the secondary lateral stigmatic areas may now be considered. In most Sebaeas the terminal organ is widely separated from the lateral ones, but in a few species the secondary stigmas may be practically confluent with the terminal one, or very close to it. It is the species of the latter type which furnish the clue to the probable origin of the secondary stigmas. The arrangement found in S. khasiana is of particular interest, as there is no line of separation between the lobed terminal stigma and the lateral secondary patches, and 
it can be seen that the stigmatic tissue is continued down the style from the point of union of the edges of the stigmatic lobes. These two decurrent lines or bands of papillae on opposite sides of the style are thus at right angles to the surfaces of the stigmatic lobes, and undoubtedly represent the first stage in the evolution of the definitely separated secondary stigmas. In this species the apical stigma scarcely projects beyond the anthers, and the decurrent papillate bands merely extend the stigmatic surface to a point slightly below the base of the anthers, being continuous above with the edges of the lobes of the stigma. S. ovata, R. Br. (Benth., Fl. Austral., iv,
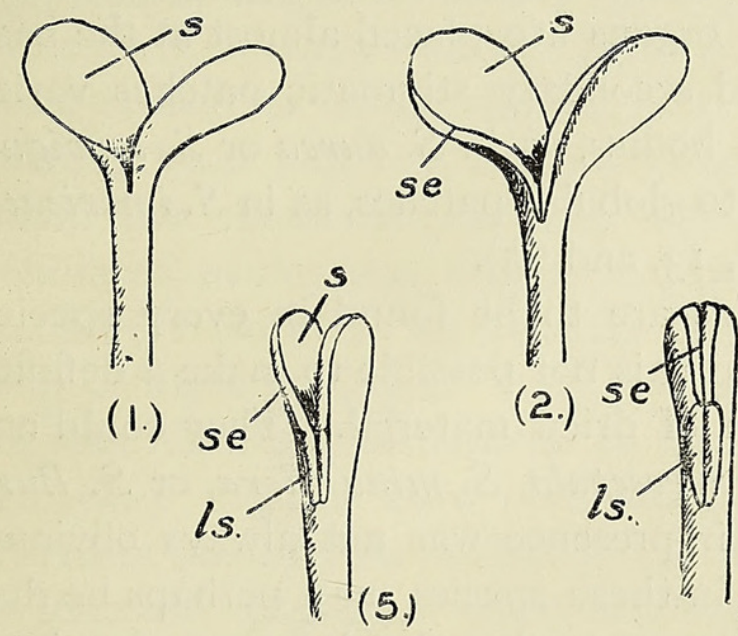

(6.)

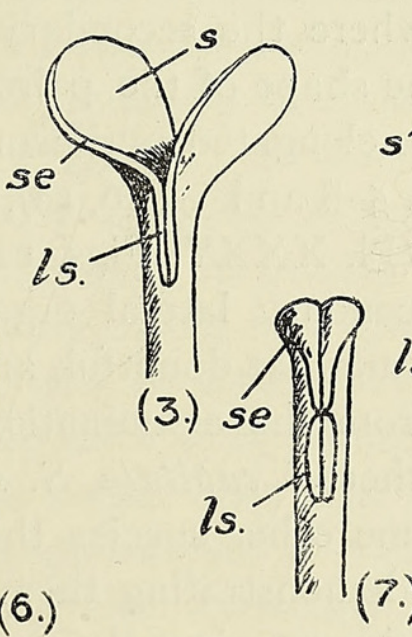

(

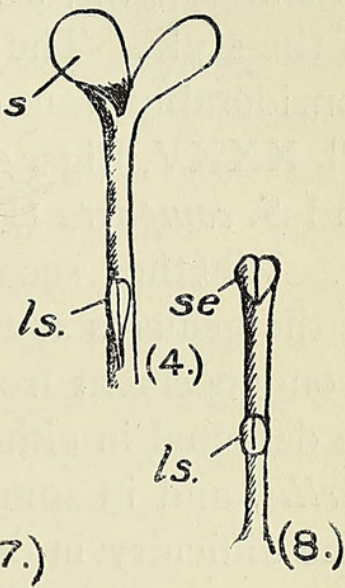

TEXT-FIG. I. Diagrammatic figures to show the supposed mode of origin of the paired lateral stigmatic patches in Sebaea. I. A simple bilabiate stigma, the inner surfaces of the lobes $(s)$ being stigmatic. 2. As Fig. I, showing the edges of lobes (se) recurved and stigmatic. 3. The recurved edges of the terminal stigmatic lobes are continued down the style (ls.) as lateral stigmatic areas. 4. The lateral stigmatic patches, consisting of two ridges, have become separated from the terminal stigma. 5. A stigma tending to become clavate by the fusion of the lobes; the edges are recurved and continued down the style as decurrent stigmatic bands. 6. A clavate stigma, the lobes being folded together, the edges forming the stigmatic band over the top of the style and continued below as the lateral or secondary stigmatic patches (ls.). 7. A more typically clavate stigma, the lateral patches slightly detached from the terminal stigma. 8. The lateral secondary stigmas (ls.) widely separated from the terminal stigma.

p. 37I), shows a similar arrangement to S. Khasiana, and, although the style in this species overtops the anthers, the stigmatic surface is decurrent from the edges of the lobes to the level of the base of the anthers, and the secondary stigmas take the form of twin ridges bearing papillae on each side of the style (P1. XXXV, Fig. 3). Sebaea membranacea (Figs. 22 and 23) and S. ecarinata ${ }^{1}$ (Figs. I9 and 20), two species found by Professor H. H. W. Pearson during the Percy Sladen Expedition to the Orange River, show the secondary stigmas in close juxtaposition to the apical one, but definitely separated from it as distinct organs. The separation of these patches of stigmatic papillae may thus be regarded as having been effected by the

1 Gentianaceae in Annals of the S. Afr. Mus., ix, pt. II, pp. 57, 58. The lateral stigmas in S. acutiloba, S. Zeyheri, S. micrantha, and $S$. intermedia are also nearly confluent with the terminal stigma. See Fl. Cap., iv. I. 
intercalation of a portion of non-papillate stylar tissue in the midst of a stigmatic region, or as being due to the loss of function of a certain amount of stigmatic tissue. In these two species the decussate arrangement of the terminal and lateral stigmatic surfaces can be clearly seen, but in others, where the secondary stigmas are situated about midway between the apex of the style and the ovary, their relation to the primary stigma is not always apparent owing to the torsion of the slender style. As far as can be seen, however, the secondary stigmas are in all cases arranged at right angles to the lobes of the primary one (Pl. XXXV, Figs. IO, I I, I 3, 2 I). The greatest separation in space of the stigmatic surfaces is seen in S. macrophylla, where the secondary organs are placed almost at the base of the style. The shape of the paired secondary stigmatic patches varies considerably from elongated pyriform bodies, as in $S$. aurea or $S$. ambigua (P1. XXXV, Figs. 5-8 and I 5, I6, I 8), to globular patches, as in S. imbricata and $S$. compacta (Pl. XXXV, Figs. I2, $\mathrm{r}_{3}$, and 25 ).

Whether secondary lateral organs are to be found in every species of the genus is somewhat doubtful, and it is not possible to make a definite pronouncement from the examination of dried material. They could not be detected in either S. capitata, S. sclerosepala, S. minutiflora, or S. Burchellii, and in some other species their presence was not always obvious. The difficulty in demonstrating them in these species may perhaps be due to the age of the flowers, since these stigmas tend to develop somewhat late. In the species included in the group Lageniades, however, no trace of the secondary stigmas could be found, and it seems probable that they are absent in this group, which, moreover, shows several marked differences from the rest of the genus. ${ }^{1}$

When young the lateral stigmatic patches are narrow simple ridges, formed by the protuberance of larger cells, but by gradual development they enlarge at the edges. They thus become broader, and each patch tends to form two prominent ridges which apparently represent the edges of the two lobes of the primary stigma. In transverse sections, therefore, each lateral patch tends to show a fairly deep median groove (P1. XXXV, Figs. 3, II, I7), though in some species, such as S. imbricata, the groove can scarcely be noticed.

The stigmatic character of these papillose swellings was further confirmed by the following experiments with the flowers of $S$. aurea, S. ambigua, S. imbricata, and $S$. confertiflora, which were carried out at the Royal Botanic Gardens. The flower buds were opened before the anthers had burst and shed their pollen, and the apical stigma was removed by a sharp scalpel (P1. XXXV, Figs. 6-8, I2, 15, I6). In some cases the anthers were also removed, and the flower was left with only the ovary

1 Marloth, in Trans. Roy. Soc. S. Afr., vol. i, pt. i, pp. 311-I4, puts forward the suggestion that all species of Sebaea may possess secondary stigmas. 
and the lower part of the style bearing the two secondary stigmatic patches.

After the removal of the apical stigma, the secondary stigmas increase very markedly in size, and in $S$. aurea and $S$. ambigua in particular they become so much enlarged that they almost block the throat of the corolla tube.

These organs in flowers so mutilated were then pollinated, when in a receptive condition, with pollen from other flowers. The subsequent increase in size was very marked, and in $S$. aurea they measured $0.75 \mathrm{~mm}$. in length when fully developed after fertilization had taken place, while in $S$. ambigua the development of papillae down the style may take place to such an extent that in several cases the secondary stigmas were found to be as much as $2.5 \mathrm{~mm}$. long (Fig. I6). In almost every instance where the apical stigma was removed and the secondary ones were pollinated, ovules were formed and seeds were eventually ripened. These seeds were found to be capable of germination, and gave rise to a fresh crop of vigorous plants. As the portion of style above the secondary stigmas, left after the removal of the apical stigma, withered up before the secondary stigmas were pollinated, it seems clear that the development of ovules can only be attributed to the pollination of these lateral patches of stigmatic papillae. Good sections of the secondary stigmas are very difficult to obtain, owing to their somewhat spongy nature when well developed, and also to the very slender nature of the style, but in several instances pollen-tubes have been seen not only growing out of the pollengrain adhering to the papillae, but also penetrating between them into the tissues of the style (Text-fig. 2).

The first experiments in removing the apical stigma were performed with Sebaea aurea in July, I908, and further experiments were made on the other species in the two following years. Control experiments consisted in removing the unburst anthers from flower-buds, to prevent self-fertilization, and in pollinating the upper stigma only, care being taken that no pollen reached the lower secondary stigmas. In these cases the amount of seed produced was small and poor, and was in marked contrast to the quality and amount of that yielded by the ovaries of the flowers mutilated by decapitation of the style. No seed was formed in flowers from which pollen was excluded. It was very noticeable that in flowers in which the anthers were not removed the lower stigmas were covered in due course with their pollen, and the amount is probably augmented, owing to the twisting of the corolla as the flower withers. The function of these, secondary stigmatic patches appears, therefore, to be a direct aid to self-fertilization. It is also evident that from their position at the throat of the corolla tube they could quite easily be cross-pollinated by insects who might visit the flower charged with pollen from another source. 
The stigma proper crowning the slender style seems somewhat out of the path of the visiting insect, if it be a small one, except in the few species with a relatively short style. As far as can be seen from an

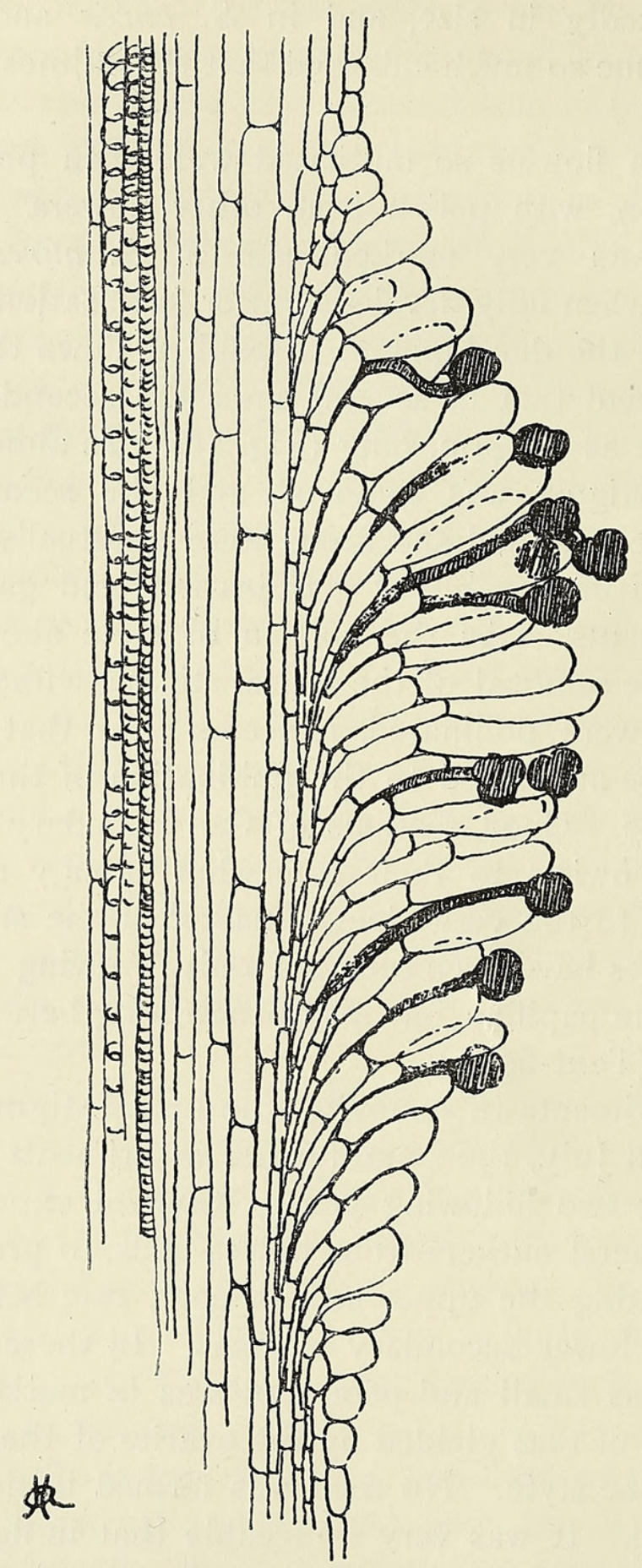

TEXT-FIG. 2. Longitudinal section through one of the secondary patches of Sebaea aurea. The terminal stigma had been removed. Pollen-grains are germinating and the tubes growing between the papillae. (Slightly diagrammatic.)

examination of a large number of herbarium specimens the terminal stigma is but rarely pollinated.

Dr. Marloth ${ }^{1}$ states that the flowers of $S$. exacoides are visited and

1 Marloth in Trans. Roy. Soc. S. Africa, vol. i, pt. i, p. 3 I 3 . 
pollinated by a minute thrips, but beyond his observations we know nothing of the insects which may visit the attractive flowers of Sebaeas under natural conditions. Should his observations be found to hold good throughout the genus, it would seem probable that the insect adapted to fertilize these flowers may have ceased to visit them, since one assumes that flowers so constructed and so conspicuous should be pollinated by fairly large insects and not by microscopic thrips. The suggestion may also be hazarded that the 'short-circuiting' of the pollination process rendered possible by the development of the secondary stigmas may be regarded in the nature of a response by the plant to its changed biological conditions. It is no doubt the case that these creeping thrips serve as excellent pollen carriers to the secondary stigmas, and that in their winged condition they may take pollen from one flower to another, but it seems very doubtful whether they would pollinate the terminal stigma except under fortuitous circumstances. The genus Pleurogyne appears to afford the only comparable case to Sebaea. Here the apical stigma is functionless, and selffertilization is no doubt rendered particularly easy by the stigmatic bands which occur on the sides of the ovary itself (Pl. XXXV, Figs. I and 2).

The foral arrangements in Sebaea might be described as an illegitimate and condensed form of heterostylism, since, though stigmas are provided at two different levels, there is no corresponding arrangement of anthers differing in length; self- rather than cross-fertilization would thus appear to be the object in view. Whether a case of true heterostylism exists in Sebaea is somewhat uncertain with our present knowledge, but it seems not improbable that S. Thodeana, Gilg., ${ }^{1}$ and S. spathulata, Steud., may represent the long and short styled forms respectively of one and the same species (Pl. XXXV, Figs. 24 and 25).

The specimens are very similar in general appearance, and the anthers, with their large black apical glands, are identical in structure; moreover, they have been gathered in the same localities. Should this supposition prove to be correct, S. spathulata will stand as the name for the dimorphic species.

The only other aberrant species of the genus, with a style shorter than the anthers, is $S$. Thomasii, ${ }^{2}$ a very distinct species. It may conceivably be conspecific with $S$. Marlothii, though this supposition is open to grave doubt because the two species are somewhat dissimilar as regards their vegetative characters. There is also, on the other hand, the possibility that the long-styled form of $S$. Thomasii may not yet have been discovered.

The genus Exochaenium, ${ }^{3}$ which is closely related to Sebaea, is of interest in this connexion, since in E. grande long-styled, short-styled, and

\footnotetext{
1 Fl. Capensis, iv, i, pp. I091, Ic92, and Kew Bull., 1908, p. 334.

${ }^{2}$ 1. c., p. 1902 , and Kew Bull, , I908, p. 335.

3 See Kew Bull., 1908, pp. 336-41 with plate.
} 
homo-styled flowers are to be found, whereas in other species the flowers may be either dimorphic or of only one type.

\title{
SUMMARY.
}

The genus Sebaea, which contains about roo species, is diplostigmatic, that is to say, in addition to the apical stigma, secondary stigmatic patches are borne on the style below the level of the anthers in nearly all the species examined.

The secondary stigmas, which are placed at right angles to the lobes of the apical stigma, appear to represent the lower part of the edges of these lobes, which have become separated from the apical stigma by the intercalation of a non-papillated portion of stylar tissue.

The flowers of Sebaea are protandrous and the anthers open in the bud; the pollen is thus shed on the secondary stigmas which are situated about the level of the throat of the corolla. Self-fertilization can thus be effected without difficulty, though cross-fertilization is not precluded.

As a result of the artificial pollination of these secondary stigmas, after removal of the apical stigma in the bud, seeds were formed from which plants have been raised. Fewer and poorer seeds were formed as a result of pollinating the terminal stigma alone.

It is suggested that the peculiar condition of these flowers may be compared to an abbreviated type of heterostylism modified to ensure selfrather than cross-pollination. Cases of peculiar types of stigmatic arrangement in other genera of this Family are mentioned, and in particular the normally heterostyled genus Exochaenium. It seems not unlikely that heterostylism may be proved to exist in at least one species of Sebaea.

\section{EXPLANATION OF PLATE XXXV.}

\author{
Illustrating Mr. A. W. Hill's paper on the genus Sebaea.
}

The figures, with the exception of Figs. 3-8 and I6-I 7 have been drawn by Miss M. Smith.

The names and numbers in brackets refer to the specimens preserved in the herbarium of the Royal Botanic Gardens, Kew, from which the drawings were made.

Fig. I. Pleurogyne carinthiaca, G. Don (Ellis, 357), showing one of the stigmatic bands. There is no stigma proper. $\times 3$.

Fig. 2. The same (Aitchison, 33), showing the two stigmatic bands on the ovary walls. $\times 6$.

Fig. 3. Sebaea ovata, R.Br. The terminal stigma is bilabiate, and there are two decurrent bands of stigmatic papillae continued down the style from the edges of the terminal stigma. 
Fig. 4. S. leiostyla, Gilg. The median portion of a style taken from a bud, showing the undeveloped lateral stigmatic patches.

Figs. 5-8. S. aurea, R.Br.

Fig. 5. The style and ovary. The terminal stigma is bilabiate, and a pair of lateral stigmatic patches occur halfway down the style.

Fig. 6. One of the pyriform lateral stigmas.

Fig. 7. A style from which the terminal stigma has been removed. The lateral stigmas are $0.75 \mathrm{~mm}$. in length.

Fig. 8. The lateral stigmas after pollination, much enlarged with conspicuous papillae.

Figs. 9-II. S. khasiana, C. B. Clarke (Ducloux, 316).

Fig. 9. The flower dissected, showing the relative positions of anthers and stigmas. $\times 3$.

Figs. Io and II. The apex of the style. The terminal stigma (s.) and lateral stigmatic patches (ls.) are almost confluent.

Figs. I2 and I3. S. imbricata, A. W. Hill (Burtt Davy, $7747 c$ ).

Fig. I2. The terminal stigma has been removed and the lateral patches, which have been pollinated, have increased largely in size. stigmas.

Fig. I3. The complete style, showing the terminal capitate-clavate stigma and secondary lateral

Figs. 14-18. S. ambigua, Cham.

Fig. 14. A complete flower, showing the terminal bilabiate stigma standing well above the anthers. The secondary stigmas are situated at the throat of the tube just below the base of the anthers.

Fig. I5. The secondary stigmas made up of three much developed bands of papillae spirally twisted. The terminal stigma has been removed.

Fig. 16. Elongated secondary stigmas $2.5 \mathrm{~mm}$. long.

Fig. I7. A cross-section of Fig. I6, showing that each secondary stigmatic patch is made up of two ridges of stigmatic papillae.

Fig. 18. A complete style with bilabiate terminal stigma and enlarged secondary patches.

Figs. 19 and 20. S. ecarinata, A. W. Hill (Pearson, 5229 ).

Fig. 19. The flower dissected, showing the relative positions of stigmas and anthers. $\times 5$.

Fig. 20. The style and ovary. The secondary stigmas are only slightly separated from the terminal stigma.

Fig. 21. S. compacta, A. W. Hill (Bolus, I 2,992). The style and ovary in different positions, showing clearly that the secondary stigmas are at right angles to the terminal stigma.

Figs. 22 and 23. S. membranacea, A. W. Hill (Pearson, 588I). stigma.

Fig. 22. The style and ovary; the secondary stigmas are almost confluent with the terminal

Fig. 23. The flower dissected to show the relative positions of the stigmas and anthers. $\times 5$.

Fig. 24. S. spathulata, Steud. (Flanagan, 2080). A flower dissected to show the long corolla tube, the anthers with their large apical glands, and the short style. $\quad \times 2$.

In some specimens (e. g. Guthrie, 488I) there is a much longer corolla tube, and the style seems to show lateral stigmatic patches confluent with the terminal stigma.

Fig. 25. S. Thodeana, Gilg (Bolus, 8216 ), a flower dissected. The style is crowned by a terminal stigma above the level of the tops of the anthers. The anthers are capped by large glands. $\times 2$. 
Antals of Botany

VoL.XXVII,PL, XXXV.

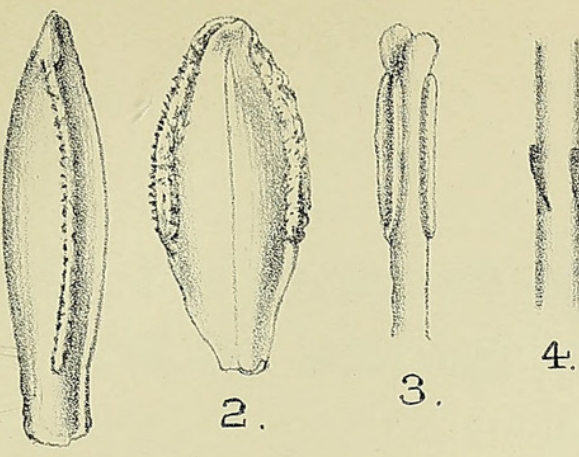

1.
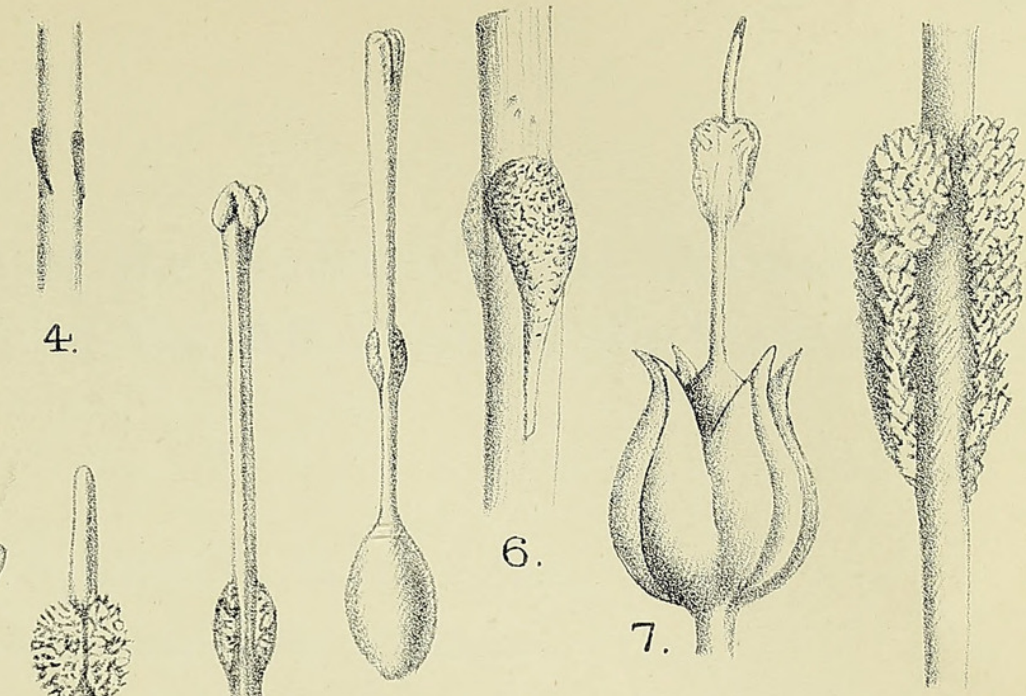

5.

8.

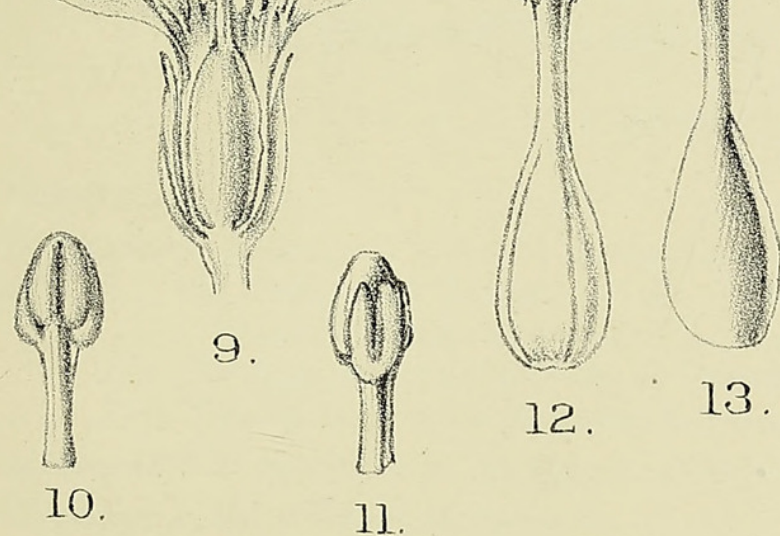

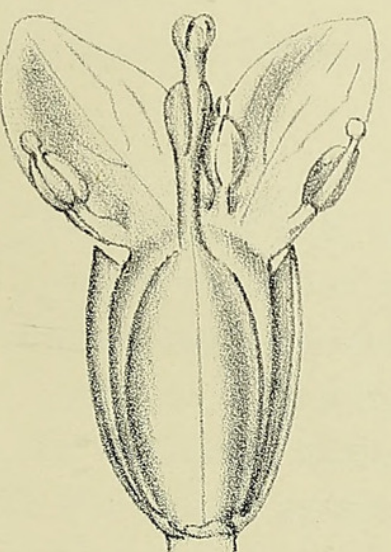

19.

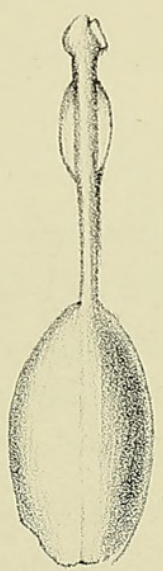

20
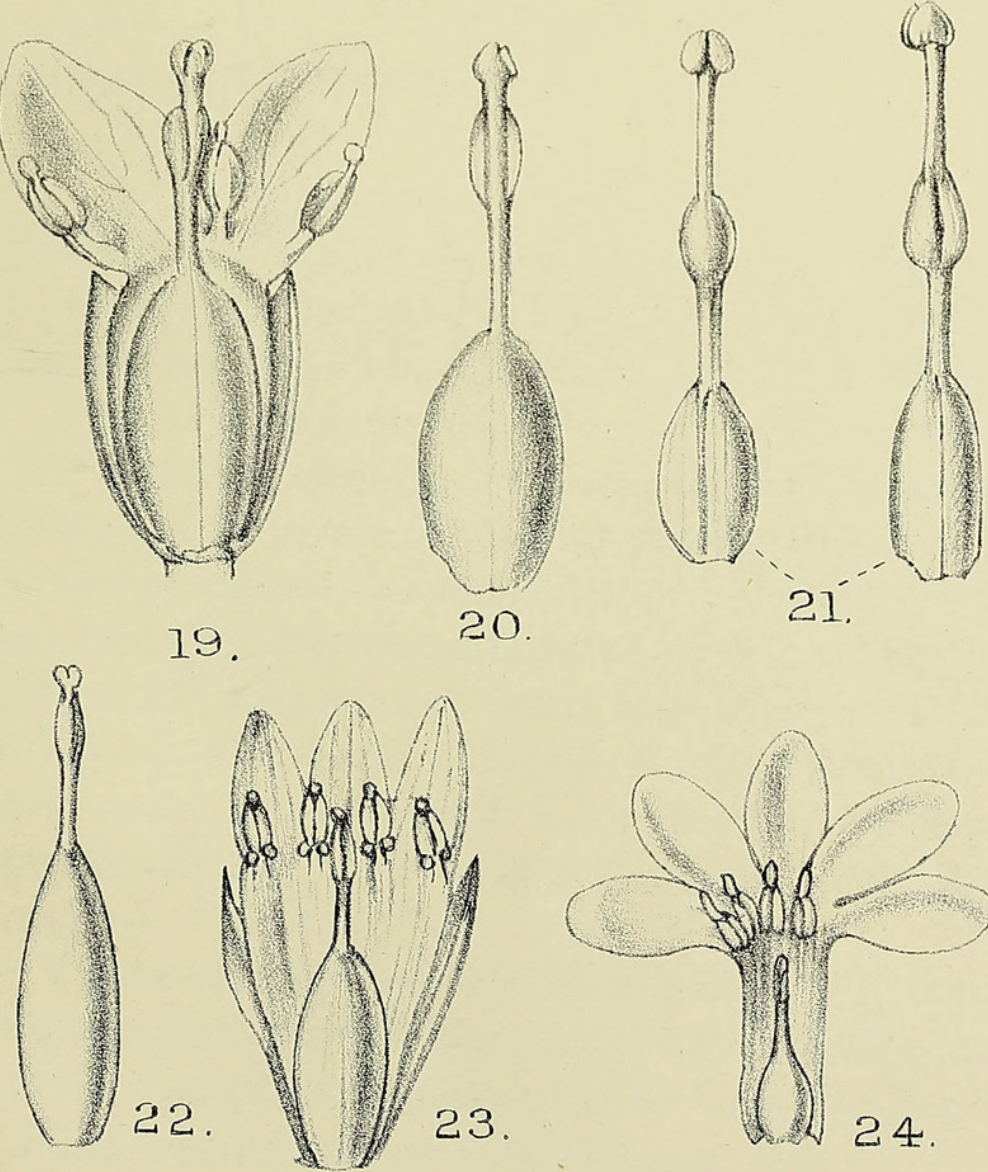

14.

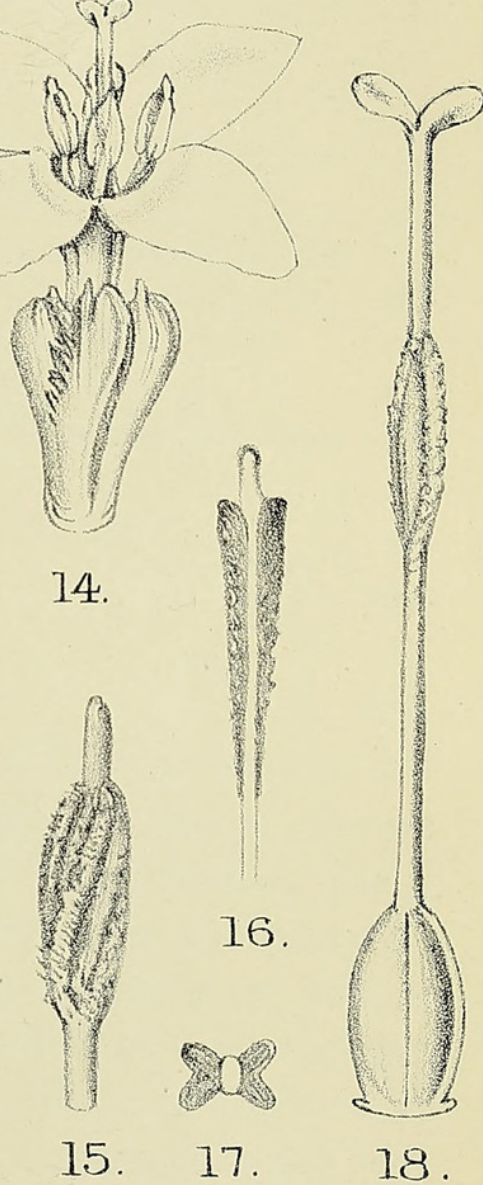

M. Smith del
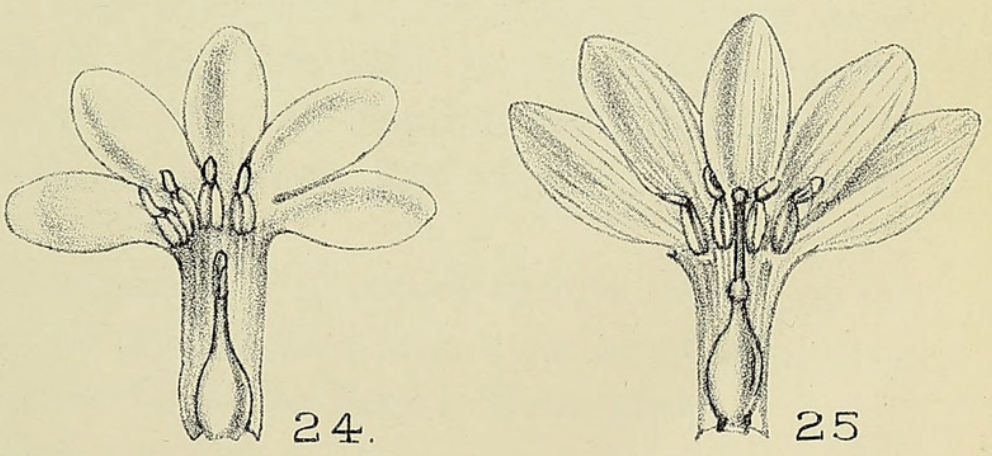

HILL - SEBAEA. 


\section{$2 \mathrm{BHL}$ Biodiversity Heritage Library}

Hill, Arthur William. 1913. "The floral morphology of the genus Sebaea." Annals of botany 27, 479-489.

https://doi.org/10.1093/oxfordjournals.aob.a089470.

View This Item Online: https://www.biodiversitylibrary.org/item/237410

DOI: https://doi.org/10.1093/oxfordjournals.aob.a089470

Permalink: https://www.biodiversitylibrary.org/partpdf/319983

\section{Holding Institution}

Smithsonian Libraries

\section{Sponsored by}

Biodiversity Heritage Library

\section{Copyright \& Reuse}

Copyright Status: Not in copyright. The BHL knows of no copyright restrictions on this item.

This document was created from content at the Biodiversity Heritage Library, the world's largest open access digital library for biodiversity literature and archives. Visit BHL at https://www.biodiversitylibrary.org. 